\title{
ANALISA MODEL KONVERSI ANTAR PERGURUAN TINGGI DENGAN PERANGKAT LUNAK PROTEGE
}

\author{
Marlina, ST, MMSi \\ Alamat Email : linabahar@ymail.com, lin4_b4h4r@plasa.com
}

\begin{abstract}
ABSTRAKSI
Transfer nilai (konversi nilai) seringkali menjadi kendala bagi perguruan tinggi satu dengan perguruan tinggi lainnya, sehingga terjadi kerancuan antara mata kuliah satu dengan mata kuliah lainnya Dengan kerancuan tersebut maka dianalisalah dan dirancang sebuah tool konversi, dimana semua mata kulih (kurikulum) yang akan dikonversi dapat menggunakan tool tersebut, sehingga semua mata kuliah yang sama dapat dilakukan konversi nilai walaupun dengan sks maupun semester yang berbeda. Batasan masalah yang dibahas adalah mengenai pemodelan pengetahuan berbasis relasi untuk konversi nilai yang dilakukan dengan ontologi, dimana pengembangan konversi dapat bersifat dinamis.

Metode yang digunakan adalah survey, indentifikasi masalah, perancangan sistem, dan implementasi sistem. Tujuan penulisan ini adalah menghasilkan model konversi yang tepat dan berguna. Sedangkan Hasil yang diharapkan membantu pihak konversi atau perguruan tinggi dalam menentukan model konversi yang baik.
\end{abstract}

Kata kunci : Konversi, Ontologi, Perguruan Tinggi

\section{PENDAHULUAN}

Mahasiswa membutuhkan pengembangan ilmu dengan berbagai cara, diantaranya melanjutkan ke jenjang lebih tinggi, misalkan dari jenjang diploma menjadi jenjang strata satu (S1).

Dengan perpindahan/melanjutkan ke jenjang lebih tinggi, maka mahasiswa dapat melakukan melakukan konversi (transfer nilai) dari mata kuliah yang telah ditempuh dan mata kuliah yang akan ditempuh.

Syarat mahasiswa yang hendak teransfer nilai (konversi nilai) harus setara atau lebih tinggi dari jenjang pendidikan dan status terakreditasi pada program studi yang dituju.Transfer nilai (konversi nilai) seringkali menjadi kendala bagi perguruan tinggi satu dengan perguruan tinggi lainnya, sehingga terjadi kerancuan antara mata kuliah satu dengan mata kuliah lainnya. Dengan kendala tersebut maka penulis mencoba untuk menganalisa dan merancang tool konversi nilai, dimana semua mata kuliah (kurikulum) yang akan dikonversi dapat menggunakan tool tersebut, sehingga semua mata kuliah yang sama dapat dilakukan konversi nilai walaupun dengan sks maupun semester yang berbeda. 
Sistem yang akan penulis rancang dengan berdasarkan teori ontologi. Ontologi merupakan teori tentang makna dari suatu objek, properti dari suatu objek, serta relasi objek tersebut yang mungkin terjadi pada suatu domain pengetahuan. Dan ontologi adalah suatu konsep yang secara sistematik menjelaskan tentang segala sesuatu yang ada atau nyata dan dapat berhubungan serta saling berkomunikasi dalam hal pertukaran informasi antara system yang berbeda.

Sedangkan perangkat lunak yang akan digunakan adalah Protege, dengan tujuan untuk pemecahan masalah dan pembuatan keputusan dalam sebuah domain dengan menyesuaiakan form untuk entry data, memasukkan data,.Maka penulis mengambil topik dengan judul "Analisa Model konversi antar perguruan tinggi dengan menggunakan Tool Protege".

Dalam mengidentifikasi masalah penulis mengangkat masalah yang akan dibahas pada bab selanjutnya, dimana masalah tersebut adalah:

1. Tidak ada standarisasi model kurikulum yang dianut bersama, sehingga terjadi perbedaan antara perguruan tinggi satu dengan perguruan tinggi lainnya

2. Dibutuhkan dinamik maping (pemetaan) untuk konversi mata kuliah transfer, sehingga menjadi jembatan penghubung antar perguruan tinggi

Dalam batasan masalah penulis akan membahas pemodelan pengetahuan berbasis relasi untuk konversi nilai yang dilakukan dengan ontologi, dimana pengembangan ontologi dapat mendukung konversi mata kuliah transfer yang mempunyai sifat konversinya adalah dinamis.

Tujuan dari penelitian ini adalah :Membuat model konversi secara konseptual dengan tujuan pada penelitian selanjutnya dapat menghasilkan tool yang sesuai dengan analisa model yang dihasilkan. Tujuan model ini adalah :

1. Untuk mempermudah proses konversi nilai dengan persepsi yang sama antara perguruan tinggi satu dengan perguruan tinggi yang lainnya.

2. Pemilihan model yang tepat untuk perancangan konversi antar perguruan tinggi yang lebih baik.

\section{TINJAUAN PUSTAKA}

\section{Definisi Ontologi}

Pengertian ontologi sangat beragam dan berubah sesuai dengan berjalannya waktu, ada beberapa definisi ontology.

Menurut Neches dan rekannya(1991) yang dikutip dari [2] mengatakan bahwa ontology yaitu : "Sebuah ontology merupakan definisi dari pengertian dasar dan relasi vocabulari dari sebuah area sebagaimana aturan dari kombinasi istilah dan relasi untuk mendefinisikan vokabulari".

Menurut Gruber (1995) yang dikutip dari [2] memberikan definisi yang sering digunakan oleh beberapa orang, definisi tersebut adalah "Ontology merupakan sebuah spesifikasi eksplisit dari konseptualisme". Berdasarkan definisi Gruber tersebut banyak orang yang mengemukakan definisi tentang ontology diantaranya Guarino dan Giaretta (1995) mengumpulkan tujuh definisi yan berkoresponden dengan syntactic dan semantic interprestasi.

Menurut Studer (1998) yang dikutip dari [2] mengatakan bahwa ontology yang mengambil acuan dari definisi yang dikemukakan oleh Gruer dan Borst, definisi tersebut adalah "Konseptualisasi mengacu kepada sebuah model abstrak dari beberapa 
fenomena di dunia dengan memiliki identifikasi konsep yang relevan dari fenomena tersebut.

\section{Tujuan Pemetaan Ontologi}

Temukan konsep yang terkait / atribut ontologies dan hubungan di antara mereka. Dibutuhkan Pemetaan secara Otomatis, maksudnya pemetaan yang dilakukan secara manual untuk menentukan skema yang cocok membutuhkan waktu lama, rawan kesalahan, dan membutuhkan proses yang mahal. Terdapat peningkatan pesat jumlah web sumber data, dan e-bisnis untuk mengintegrasikan secara giliran untuk menunjukkan kemegahan ontologies dan data yang akan dipetakan. Daerah yang sama di banyak penelitian yang dilakukan adalah "Skema Pencocokan"

\section{PROTEGE}

Protege adalah perangkat lunak bantu yang digunakan untuk mengembangkan sistem berikut Knowledge Base system. Aplikasi yang dikembangkan oleh protege digunakan dalam pemecahan masalah dan pembuatan keputusan dalam sebuah domain. Protege dikembangkan oleh sebuah organisasi yang bernaung di bawah Stanford, yang mengambil spesialisasi dibidang ontology.

Protege merupakan sebuah alat yang digunakan untuk membuat sebuah domain ontology, menyesuaikan form untuk entry data, dan memasukkan data. Berbagai format penyimpannya seperti OWL, RDF, XML dan HTML. Protege menyediakan kemudahan plug and play yang membuatnya fleksibel untuk pengembangan prototype. Protege dibuat dengan menggunakan bahasa pemrograman Java. Semua alat-alat dalam protege dapat digunakan melalui Graphical User Interface (GUI) dengan menyediakan Tab untuk masing-masing bagian dan fungsi standar. Class Tab dalam editor ontology berfungsi untuk mendefinisikan class dan hirarki class, property dan nilai property tersebut, relasi antara class dan property dari relasi tersebut.

Protege memvisualisasikan hubungan subclass dalam tree, mendukung berbagai penurunan (multiple inheritance) dan root pada hirarki class yang terbentuk adalah class "THING"

\section{METODOLOGI PENELITIAN}

Langkah yang digunakan dalam penelitian adalah :

Survey adalah kegiatan studi lapangan yaitu :

1. Melakukan wawancara ke pihak perguruan tinggi diantaranya Petugas konversi, Ketua Jurusan dan beberapa mahasiswa.

2. Melakukan pengumpulan data yang terkait sebagai bahan pertimbangan dalam menentukan parameter penilaian.

Untuk identifikasi masalah, parameter yang dibuat sebagai parameter penilaian dengan cara penentuan proses penilaian yang akan digunakan dalam model value nilai. 


\section{PERANCANGAN MODEL KONVERSI}

Dari hasil survey dan identifikasi masalah, maka dibuatlah suatu Proses Transfer nilai untuk mempermudah terjadi transfer nilai. Adapun proses yang dapat dilakukan adalah Universitas $\mathrm{Y}$ ingin melakukan konversi nilai pada dari universitas $\mathrm{X}$, maka dibukalah website, dimana aplikasi yang tersedia dapat membantu dia untuk mencarikan informasi di web mengenai mata kuliah yang terkonversi, sebutlah aplikasi ini dengan nama agent konversi. Kemudian Universitas $\mathrm{Y}$ tersebut meminta agent untuk menampilkan

Informasi tentang permasalahan mata kuliah satu dengan mata kuliah yang lain. Karena website yang dimiliki oleh beberapa universitas telah di representasikan dengan OWL, maka agent dengan mudah dapat menyimpulkan informasi yang didapatkan dari berbagai universitas dan menampilkan hasil akhirnya kepada petugas konversi nilai tersebut.

Proses yang dilakukan oleh agent untuk mendapatkan informasi yang diinginkan petugas konversi nilai adalah :

1. Agent mencari informasi tentang mata kuliah pada beberapa universitas (bisa diasumsikan tiga universitas)

2. Dari beberapa website universitas yang didapat, agent melakukan penalaran bahwa mata kuliah yang hampir sama dengan sks yang berbeda dapat diakui dalam pengakuan dari beberapa universitas.

3. Dan mata kuliah yang sama dengan sks yang sama dapat diakui pula dalam pengakuan konversi dari beberapa universitas.

4. Setelah itu agent mencari dari website pada beberapa universitas sehingga informasi yang dibutuhkan dapat disajikan kepada petugas konversi nilai.

Keuntungan yang didapatkan pada aplikasi ini adalah :

1. Waktu yang diperlukan lebih singkat (cepat)

2. Pekerjaan pencarian yang dilakukan manusia dapat digantikan oleh mesin, sehingga ia bisa mengerjakan hal lain yang lebih efektif.

3. Membantu mahasiswa agar tidak perlu lagi melakukan konversi nilai di berbagai universias, dengan aplikasi tersebut cukup di salah satu universitas dapat mewakili dari beberapa universitas lainnya dalam pengakuan konversi.

Proses Bisnis yang terjadi pada sistem adalah

1. Calon Mahasiswa memilih jurusan

(a) Jurusan Teknik Informatika

(b) Jurusan Sistem Informasi

(c) Jurusan Sistem Komputer

2. Calon Mahasisa Membeli formulir ke Front Office

(a) Calon Mahasiswa membayar formulr pendaftaran di Front Office

(b) Front $\mathrm{O} \pm$ ce menyerahkan tanda bukti pembelian dan formulir data calon mahasiswa

3. Calon Mahasisa menyerahkan prasyarat pendaftaran yang terdiri dari

(a) Ijazah, Traanskrip untuk mahasiswa yang lanjutan dari D3 ke S1

(b) Surat Keterangan pindah kuliah dari kampus yang bersangkutan, transkrip nilai sekolah asal yang sudah ditempuh beserta ijazah terakhir untuk mahasiswa pindahan.

4. Front Office menyerahkan prasyarat calon mahasiswa ke bagian petugas konversi. 
5. Petugas konversi melakukan penyeleksian mata kuliah dan diserahkan ke jurusan untuk disahkan.

6. Petugas konversi menyerahkan bukti konversi ke Front Office.

7. Front Office menyerahkan bukti konversi ke calon mahasiswa

Dari hasil proses bisnis diatas dapat digambarkan pada gambar

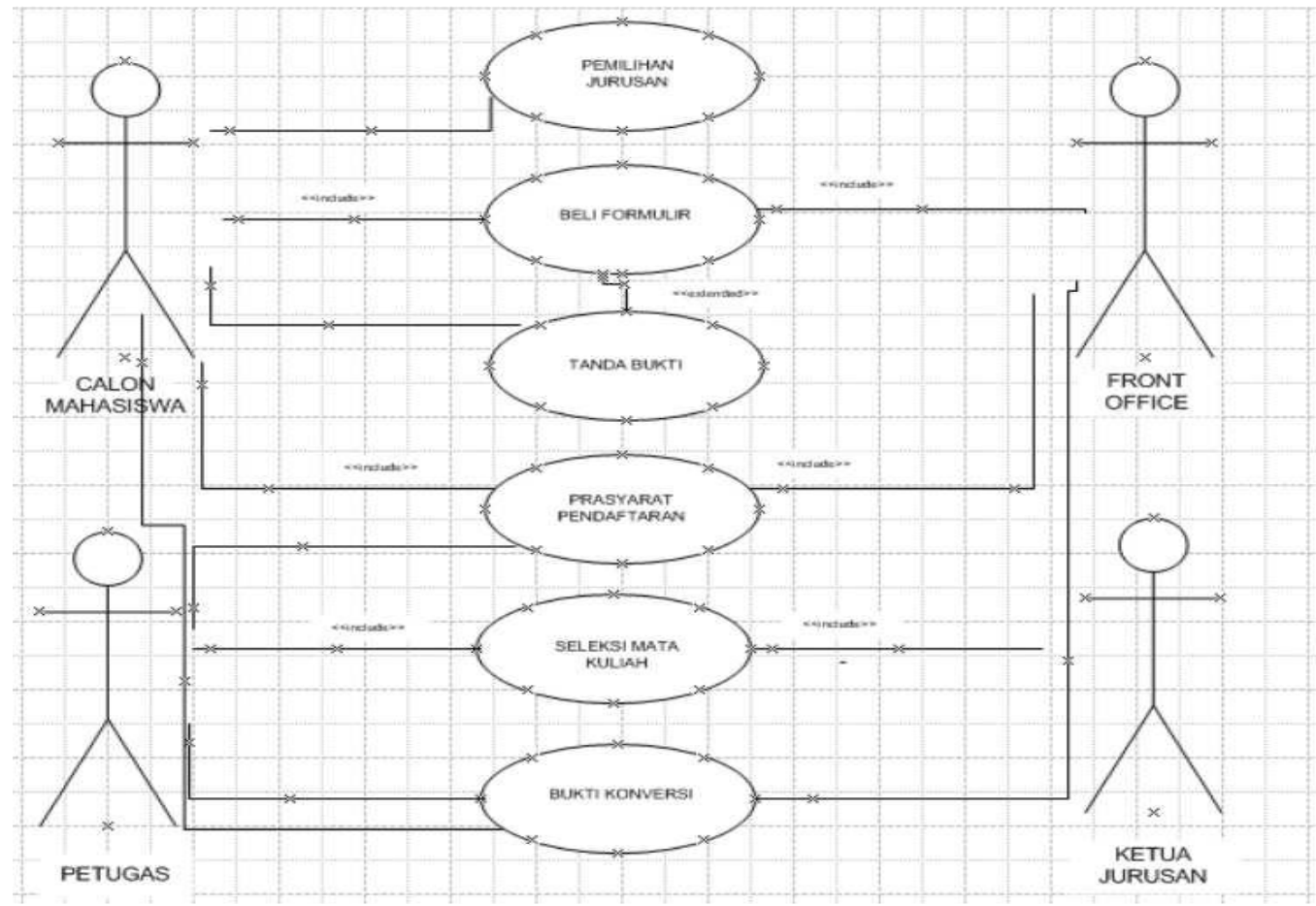

Gambar 1: Proses Bisnis

Apabila kita hendak memecahkan proses bisnis, maka hasil yang kita dapatkan adalah Proses Bisnis Pendaftaran Mahasiswa, Proses Bisnis Konversi

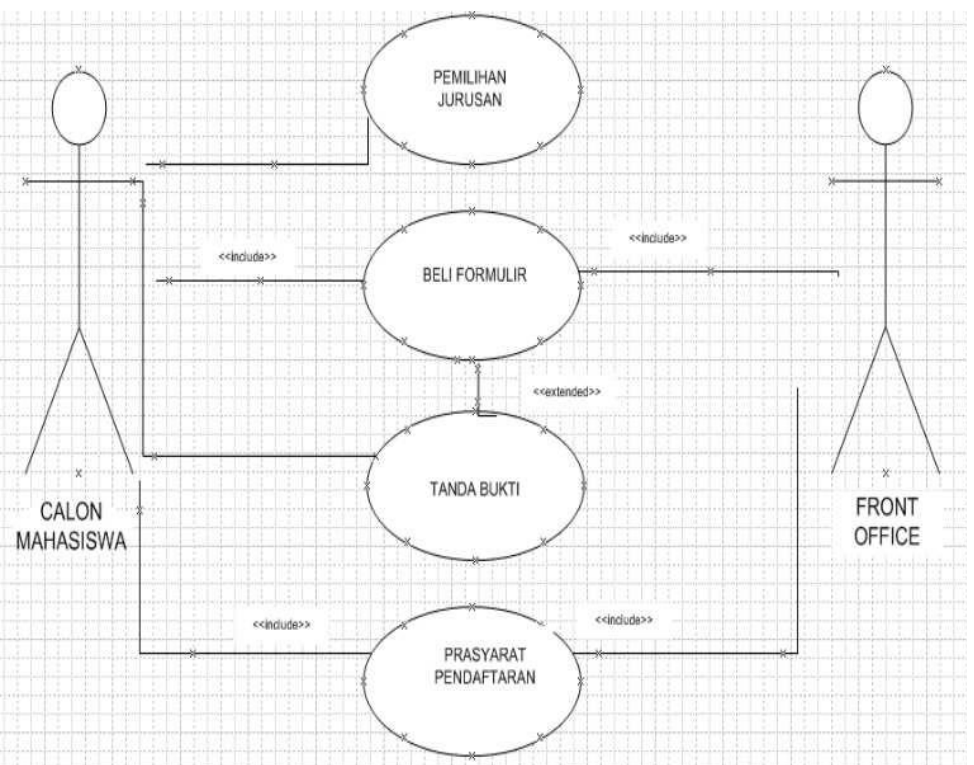

Gambar 2: Model Proses Bisnis Daftar Mahasiswa 


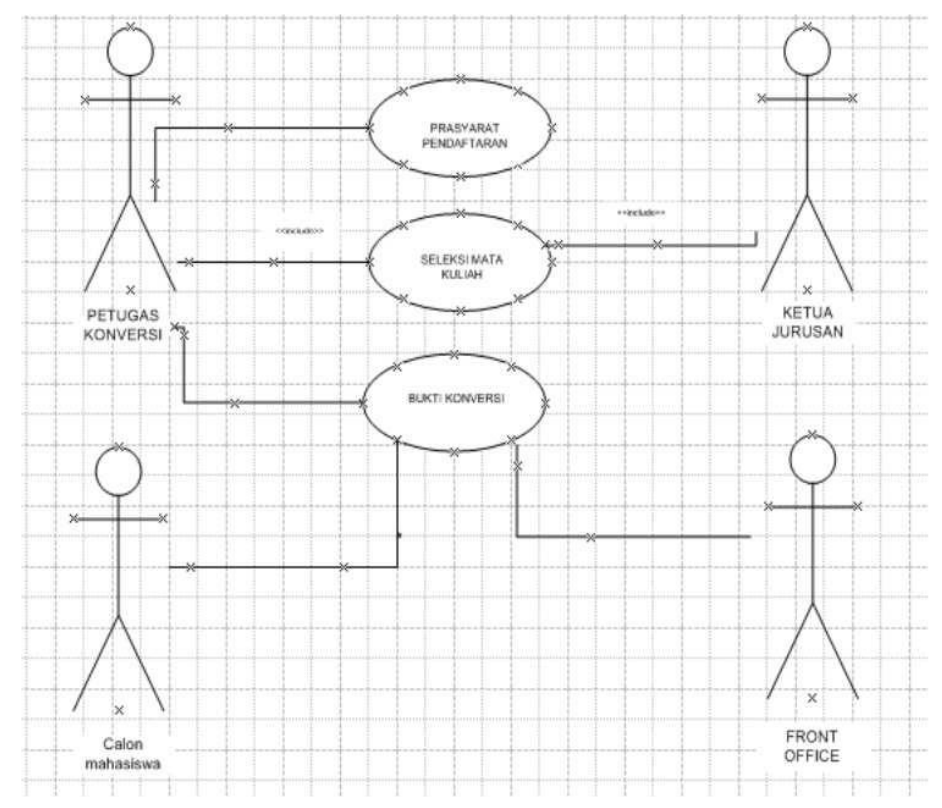

Gambar 3 : Model Proses Bisnis Daftar Konversi

\section{Langkah Proses Mapping}

Dalam penulisan ini Mapping yang diusulkan ada 3 (tiga)bentuk, sehingga terdapat model konversi 1 (kesatu), model konversi 2 (kedua) dan model konversi 3(ketiga).

1. Proses Mapping untuk model konversi 1 (kesatu) terdiri atas Sebuah universitas hendak melakukan konversi, maka root akan mencari dari class mata kuliah dengan Property Namamk, sks dan semester. Dan class jurusan dengan roperty Jurusan, JenisJur, sedangkan class Kurikulum dengan properties NamaKur, Jurusan NamaMk.

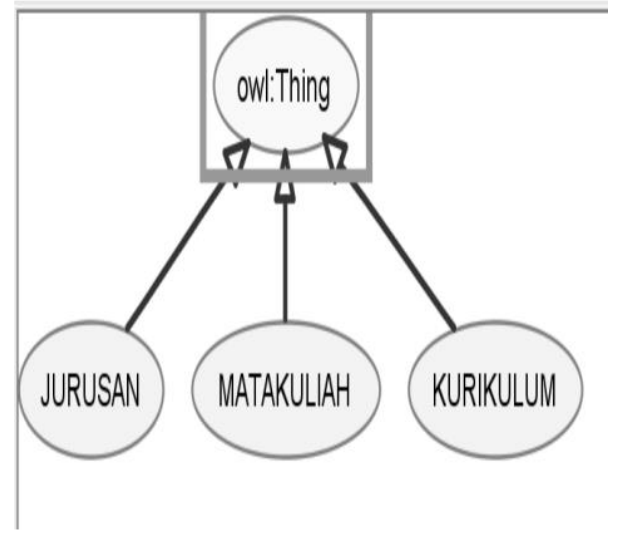

Gambar 4 : Proses Mapping Konversi 1 
2. Proses Mapping untuk model konversi 2 (kedua) terdiri atas Owl:Thing merupakan Root bagi konversi dengan terdiri atas class Kurikulum dengan properties NamaKur. Class Kurikulum memiliki subclass Sistem Informasi, Sistem Komputer dan Teknik Informatika. Sistem Informasi memiliki properties Namamk, sks, dan semester. Sistem Komputer dengan properties Namamk, sks, semester. Teknik Informatika dengan properties Namamk, sks dan semester.

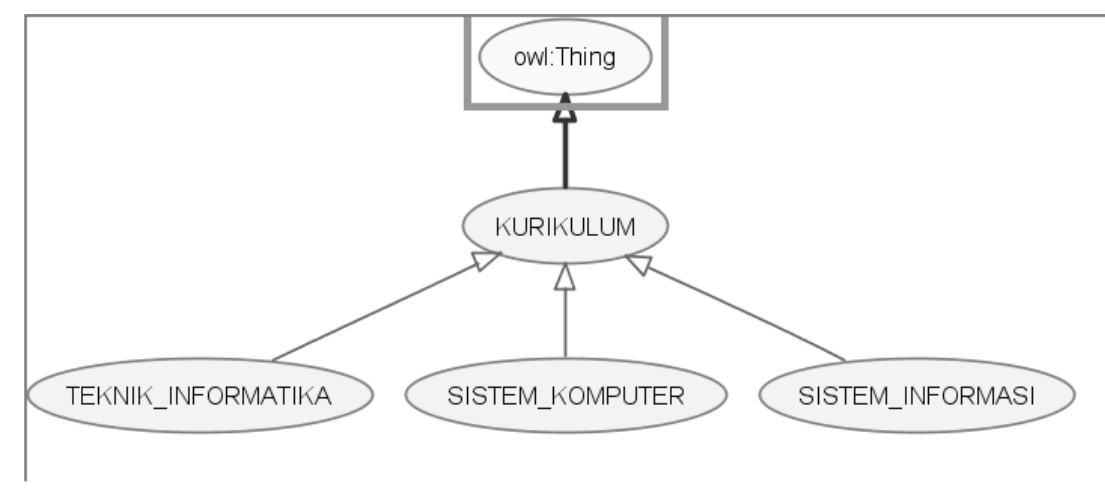

Gambar 5 : Model Mapping Konversi 2

3. Proses Mapping untuk model konversi 3 (ketiga) terdiri atas Owl:Thing merupakan Root bagi konversi. Root memiiki class system informasi, class sistem komputer dan class teknk informatika. Sedangkan sistem informasi memiliki properties Namakur, Namamk, sks dan semester. Untuk class sistem komputer memiiki properties Namakur, Namamk, sks dan semester. Dan class teknik informatika memiliki properties Namakur, Namamk, sks dan semester.

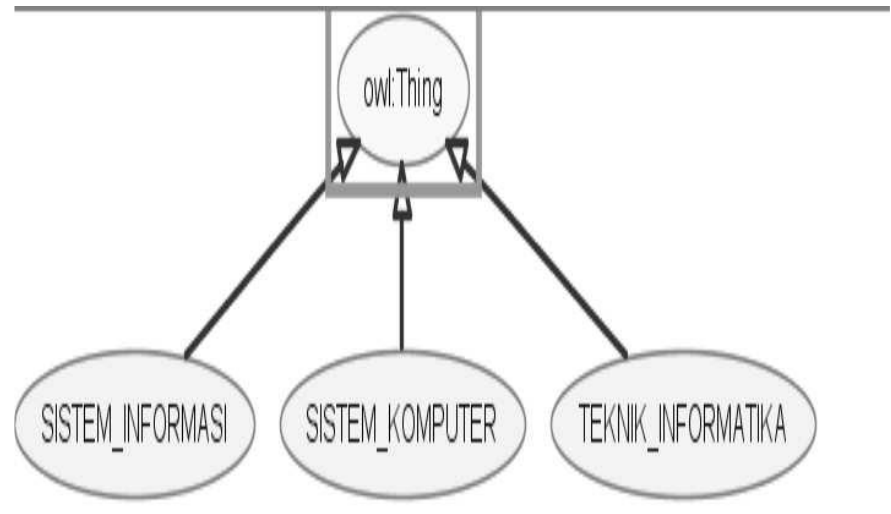

Gambar 6 : Model Mapping Konversi 3

Representasi Mapping dengan Look-Up Table

Dari hasil Mapping diatas, maka dapat dibuatlah Dictionary Data. Dictionary Data pada ketiga model konversi dapat dijelaskan bahwa setelah kita menentukan class beserta properties, maka kita ke tab Form, di tab ini akan muncul data dictionary (struktur data) yang telah dibuat berdaasarkan class dan properties yang telah dibuat sebelumnya. 
Untuk model konversi 1 (kesatu) terdapat dictionary data yaitu :

1. Data Dictionary Kurikulum, dengan Propertiesnya ('Namakur, string (15) not null, Namamk, string(20) not null, Jurusan, string(15) not null, primary key(Namakur), foreign key(Namamk), foreign key(Jurusan). Yang artinya Kurikulum memiliki properties Namakur, sedangkan Jurusan, merupakan foreign key (kunci tamu), Namamk, merupakan kunci tamu (foreign key). Jadi jurusan "mengacu" pada tabel jurusan, dan namamk "mengacu" pada tabel mata kuliah.

2. Data Dictionary Jurusan, dengan propertiesnya ('Jurusan: String (15) not null, JenisJur: String(10), primary key (Jurusan)'). Yang artinya Class Jurusan memiliki properties Jurusan dan JenisJur.

3. Data Dictionary Matakuliah ('NamaMk: String(20) not null, , semester: String (2), Sks: String (2), primary key (NamaMk)') Yang artinya MataKuliah memiliki properties Namamk, sks, semester.

Untuk model konversi 2 (kedua) terdapat dictionary data yaitu :

1. Data Dictionary Kurikulum ('NamaKur: String (10)not null, primary key (NamaKur)'). Yang artinya Kurikulum memiliki properties Namakur, dan merupakan kunci utama dari Kurikulum.

2. Data dictionary Sistem Informasi ('NamaMk: String(20) not null, semester String (2), Sks: String (2), Namakur: string(10) not null, primary key (NamaMk), foreign key (Namakur)'). Yang artinya Sistem Informasi memiliki properties Namamk, semester,sks, sedangkan Namakur merupakan kunci tamu dari tabel kurikulum, yang artinya Namakur "mengacu" pada tabel kurikulum.

3. Data dictionary Sistem Komputer ('NamaMk: String(20) not null, semester: String (2), Sks: String (2), Namakur: string(10) not null, primary key (NamaMk), foreign key (Namakur)') Yang artinya Sistem Komputer memiliki properties Namamk, semester, sks, sedangkan Namakur merupakan kunci tamu dari tabel kurikulum, yang artinya Namakur "mengacu" pada tabel kurikulum.

4. Data dictionary Teknik Informatika ('NamaMk: String(20) not null, semester: String (2), Sks: String (2), Namakur: string(10) not null, primary key (NamaMk), foreign key (Namakur)'). Yang artinya Teknik Informatika memiliki properties Namamk, semester, sks, sedangkan Namakur merupakan kunci tamu dari tabel kurikulum, yang artinya Namakur "mengacu" pada tabel kurikulum.

Untuk model konversi 3 (ketiga) terdapat dictionary data yaitu :

1. Data dictionary Sistem Informasi ('NamaMk: string (20) not null, NamaKur: string(15) not null, semester: string(2), sks: string(2), superkey (NamaMk), primary key (NamaKur)'). Yang artinya Sistem Informasi memiliki properties NamaMk, NamaKur,semester dan sks, dimana NamaMk sebagai superkey, NamaKur sebagai primary key, semester, sks.

2. Data dictionary Sistem Komputer ('NamaMk: string (20) not null, NamaKur: string(15) not null, semester: string(2), sks: string(2), superkey (NamaMk), primary key (NamaKur)'). Yang artinya Sistem Komputer memiliki properties NamaMk, NamaKur,semester dan sks, dimana NamaMk sebagai superkey, NamaKur sebagai primary key, semester, sks.

3. Data dictionary Teknik Informatika ('NamaMk: string (20) not null, NamaKur: string(15) not null, semester: string(2), sks: string(2), superkey (NamaMk), primary key (NamaKur)'). Yang artinya Teknik Informatika memiliki properties NamaMk, 
NamaKur,semester dan sks, dimana NamaMk sebagai superkey, NamaKur sebagai primary key, semester, sks.

\section{Pengujian}

Dalam pengujian ini penulis membangun sistem berbasis aturan untuk penilaian model konversi nilai dengan verifikasi maka sistem dapat melacak kesalahan dalam membuat aturan. Sedangkan generate rule adalah bagaimana sistem dapat membuat aturan-aturan berdasarkan parameter, bobot tiap parameter, pilihan dan nilai yang ada pada tiap parameter.

Sebelum membandingkan ketiga konversi tersebut, maka penulis melakukan parameter perbandingan untuk 3(tiga) model konversi tersebut. Proses penilaian digunakan model value nilai yang digunakan sebagai berikut :

Tabel 1

Parameter Pengujian

\begin{tabular}{|c|c|c|}
\hline Kriteria & Status & Keterangan \\
\hline 3 Class & Berhubungan & Baik \\
\hline 2 Class & Berhubungan & Kurang Baik \\
\hline 1 Class & Berhubungan & Jelek \\
\hline Semua Class & Tidak berhubungan & Terlalu Jelek \\
\hline
\end{tabular}

Sumber : Analisa dari basis data

Dalam sistem berbasis aturan ini, hanya digunakan operasi AND karena dalam implementasi penilaian model konversi ini hanya berlaku operasi $A N D$.

Dari parameter pengujian diatas, maka algoritma yang didapatkan :

If (kriteria $=$ ' 3 Class') and (Status $=$ 'Berhubungan') then

Keterangan $=$ 'Baik'

Else

If $($ kriteria $=$ ' 2 Class') and (Status $=$ 'Berhubungan') then

Keterangan $=$ 'Kurang Baik'

Else

If $($ kriteria $=$ ' 1 Class $)$ and (Status $=$ 'Berhubungan') then

Keterangan $=$ 'Jelek'

Else

Endif,

Keterangan $=$ 'Terlalu Jelek'

Endif,

Endif. 
Berdasarkan algoritma diatas, maka kita dapat melakukan pengujian, langkah pertama kita lakukan pembuatan konversi untuk model konversi 1 (kesatu).

1. Dari gambar dibawah dapat dijelaskan bahwa konversi 1 (kesatu) memiliki properties Namakur,Jurusan, JenisJur, NamaMk, sks, dan semester. Perhatikan pada class pemetaan konversi 1 (kesatu), dimana NamaKur "mengacu" pada class kurikulum, Jurusan dan JenisJur "mengacu" pada class Jurusan, sedangkan NamaMk, sks dan semester "mengacu" pada class Mata kuliah.

Tabel 2

Pemetaan untuk Konversi 1

Pemetaan tabel Konversi 1 (Kesatu)

\begin{tabular}{|c|c|c|c|c|c|c|}
\hline NamaKur & & Jurusan & JenisJur & NamaMk & sks & semester \\
\hline & 2003 & Sistem Informasi & Strata Satu & Allabar & & 2 \\
\hline & 2003 & Sistem Komputer & Strata Satu & Aljabar & & 3 \\
\hline & 2003 & Tekrikinformatika & Strata Satu & Alliabar & & 3 \\
\hline & 2000 & Sistem Informasi & Strata Satu & Aliabar dan Linier & & 3 \\
\hline & 2003 & Teknik Informatika & Strata Satu & Logika Algontma & & 3 \\
\hline & 2003 & Sistem Informasi & Strata Satu & Algoritma & & 3 \\
\hline & 2003 & Sistem Komputer & Strata Satu & Algoritma Pemrograman & & 2 \\
\hline & 2006 & Tekrikinformatika & Strata Setu & Logika Algoritma & & 2 \\
\hline & 2003 & Sistem Informasi & Strata Satu & Perancangan Sistem Inf. & & 3 \\
\hline & 2003 & Sistem Komputer & Strata Satu & Analisa dan Perancangan Sistem Inf. & & 3 \\
\hline & 2003 & Teknik Informatika & Strata Satu & Analisa Sistem Informasi & & 4 \\
\hline & 2008 & Tekrikinformatka & Strata Satu & Analisa Sistem Informasi & & 3 \\
\hline
\end{tabular}

Langkah kedua kita lakukan pembuata konversi untuk model konversi 2 (kedua).

2. Dari gambar dibawah dapat dijelaskan bahwa konversi 2 (kedua) memiliki properties Namakur,NamaMk, sks, dan semester. Perhatikan pada tabel pemetaan konversi 2 (kedua), dimana NamaKur "mengacu" pada class kurikulum, sedangkan NamaMk, sks dan semester "mengacu" pada class Mata kuliah.

Tabel 3

Pemetaan untuk Konversi 2

Pemetaan tabel Konversi 2 (Kedua)

\begin{tabular}{|c|c|c|c|}
\hline NamaKur & NamaMk & sks & semester \\
\hline 2003 & Aljabar & 2 & 3 \\
\hline 2003 & Aljabar & 3 & 2 \\
\hline 2003 & Alliabar & 3 & 2 \\
\hline 2006 & Aliabar dan Linier & 3 & 3 \\
\hline 2003 & Logika Algoritma & 3 & 2 \\
\hline 2003 & Algoritma & 3 & 4 \\
\hline 2003 & Algoritma Pemrograman & 2 & 3 \\
\hline 2006 & Logika Algoritma & 2 & 3 \\
\hline 2003 & Perancangan Sistem Inf. & 3 & 4 \\
\hline 2003 & Analisa dan Perancangan Sistem Inf. & 3 & 5 \\
\hline 2003 & Analisa Sistem Informasi & 4 & 6 \\
\hline 2008 & Analisa Sistem Informasi & 3 & 5 \\
\hline
\end{tabular}


Langkah ketiga kita lakukan pembuata konversi untuk model konversi 3 (ketiga).

3. Dari gambar dibawah dapat dijelaskan bahwa konversi 3 (ketiga) memiliki properties Namakur,NamaMk, sks, dan semester. Perhatikan pada tabel pemetaan konversi 3 (ketiga), dimana NamaKur, NamaMk, sks dan semester "mengacu" pada class sistem informasi, atau class sistem komputer dan atau class teknik informatika

Tabel 4

Pemetaan untuk Konversi 3

Pemetaan tabel Konversi 3 (Ketiga)

\begin{tabular}{|r||l|r|r|}
\hline NamaKur & NamaMk & sks & semester \\
\hline 2003 & Aljabar & 2 & 3 \\
\hline 2003 & Aljabar & 3 & 2 \\
\hline 2003 & Aljabar & 3 & 2 \\
\hline 2006 & Aljabar dan Linier & 3 & 3 \\
\hline 2003 & Logika Algoritma & 3 & 2 \\
\hline 2003 & Algoritma & 2 & 4 \\
\hline 2003 & Algoritma Pemrograman & 2 & 3 \\
& Logika Algoritma & 3 & 3 \\
\hline 2003 & Perancangan Sistem Inf. & 4 \\
\hline 2003 & Analisa dan Perancangan Sistem Inf. & 3 & 5 \\
\hline 2003 & Analisa Sistem Informasi & 4 & 6 \\
\hline 2008 & Analisa Sistem Informasi & 3 & 5 \\
\hline & & & \\
\hline
\end{tabular}

\section{Hasil Pengujian}

Berdasarkan ketiga model diatas dan berdasarkan parameter penilaian, maka hasil pengujian tersebut adalah :

1. Model konversi 1 (kesatu) memiliki 3 (tiga) class yang saling berhubungan untuk pemetaan konversi, yaitu class mata kuliah, class jurusan dan class kurikulum. Dimana class mata kuliah memiliki properties NamaMk, semester dan sks, Class jurusan memiliki jurusan, dan jenisjur, sedangkan class kurikulum memiliki properties Namakur. Apabila kita tinjau dari tabel parameter pengujian diatas, maka model konversi 1(kesatu) tersebut dinyatakan "Baik".

2. Model konversi 2 (kedua) adalah model memiliki 2 (dua) class yang saling berhubungan untuk pemetaan konversi, yaitu class kurikulum dan class sistem informasi atau class teknik informatika atau class sistem komputer. Dimana properties kurikulum adalah Namakur, sedangkan class sistem komputer atau class teknik informatika atau class sistem informasi adalah NamaMk, sks, dan semester. Apabila kita tinjau dari tabel parameter pengujian diatas, maka model konversi 2 (kedua) tersebut dinyatakan "Kurang Baik"

3. Pemetaan model konversi 3(ketiga) adalah model yang buruk, dikarenakan pada model konversi 3 (ketiga) memiliki 1 (satu) class untuk pemetaan konversi, yaitu class sistem informasi atau sistem komputer atau teknik informatika, sedangkan propertiesnya adalah Namakur, NamaMk, sks dan semester. Apabila kita tinjau dari tabel parameter pengujian diatas, maka model konversi 3 (ketiga) tersebut dinyatakan "Jelek". 


\section{Kesimpulan}

Konversi merupakan suatu transfer nilai mata kuliah dengan tujuan membantu universitas untuk melakukan alih kredit/transfer nilai dari universitas $\mathrm{X}$, universitas $\mathrm{Y}$ dan universitas $\mathrm{Z}$ atau melakukan transfer nilai pada universitas yang sama (pemutihan). Hasil rancangan dari konversi yang telah penulis buat hanyalah merancang dari class diagram, properties, ontoviz dan owlviz.

Dan penulis mencoba membandingkan 3 (tiga) model konversi serta melakukan pengujian dari ketiga model konversi ini, dengan menggunakan tabel parameter pengujian diatas, dan melakukan algoritma, sebagai berikut :

Jika kriteria $=3$ class dan status $=$ berhubungan, maka

Keterangan $=$ Baik

Atau

Jika kriteria $=2$ class dan status $=$ berhubungan, maka

Keterangan $=$ Kurang Baik

Atau

Jika kriteria $=1$ class dan status = berhubungan, maka

Keterangan $=$ Jelek

Atau

Keterangan $=$ Terlalu Jelek

Berdasarkan tabel parameter pengujian dan algoritma yang digunakan, maka dapat diambil kesimpulan bahwa

1. model konversi 1 (kesatu) dengan menggunakan 3 class yang saling berhubungan, maka penilaiannya dinyatakan "Baik"

2. Model konversi 2 (kedua) dengan menggunakan 2 class yang saling berhubungan, maka penilaiannya dinyatakan "Kurang Baik"

3. Model konversi 3 (Ketiga) dengan menggunakan 1 class yang saling berhubungan, maka penilaiannya dinyatakan "Jelek"

\section{Saran}

Dalam penelitian ini hanya membuat ontology secara konseptual, sehingga untuk menjalankan ontology yang lebih baik dibutuhkan Label Matching, Internal Struktural dan Eksternal Struktural, sehingga menghasilkan model ontologi yang lebih baik dan berguna bagi petugas konversi.

\section{Daftar Pustaka}

1. Wicaksana, IWS,2005, Pentingnya Peranan Bahasa dalam Interoperabilitas Informasi berbasiskan Komputer karena Keragaman Semantik, Prosiding Seminar Ilmiah Nasional (PESAT 2005),Universitas Gunadarma, Jakarta.

2. Wicaksana, Lintang, 2007, "Pengujian Tool Ontology Engineering"

3. Paperwgbis.abmutiara.info, 2007, "Bahasa Tool Ontology"

4. Ariel, Renee J.Miller, dkk,2006, "Nested Mappings: Schema Mapping Reloaded" 
5. Http://iwayan.info//Research/Understanding/ThesisBourogne/Thesis-IwayanFinal/mainthesis/node20.html

6. Lintang Y, "Pemeliharaan Agreement Dengan Menggunakan Perubahan Skema dan Ontologi Pada Lingkungan PEER-TO-PEER (P2P)", (2007)

7. http://www.protege.com

8. Shvaiko, Pavel and Euzenat, Jerome,2006, "A Survey of Schema based Matching Approaches", University of Trento, Povo, Trento, Italy

9. Catur Bawa, Daniel Siahaan, Februari 2009, Case Tool Untuk Pemodelan Semantik Data dalam WEB Ontology Language (OWL), Prosiding Seminar Nasional Manajemen Teknologi IX Program Studi MMT-ITS, Surabaya

10. Azhari dan Minurita Sholichah,Mei 2006, 67-76, MODEL ONTOLOGI UNTUK INFORMASI JADWAL PENERBANGAN MENGGUNAKAN PROTEGE, Jurnal Informatika Vol.7, NO. 1, Jurusan Teknik Informatika, Fakultas Teknologi Industri Universitas Kristen Petra

11. Protege,2005 http://protege.stanford.edu/.

12. Visser, U. and Schuster, G. Finding and Integration of Information a Proactical Solution for the Semantic Web. In Euzenat, J., Gomez-Perez, A., Guarino, N., and Stuckenschmidt, H., editors, Proceedings of ECAI 02, Workshop on Ontologies and Semantic Interoperability, pages 73-78, Lyon, France.

13. Yannis Kalfoglou and Marco Schorlemmer,2005, "Ontology Mapping: The State of the Art", Dagstuhl Seminar Proceedings 04391 Semantic Interoperability and Integration http://drops.dagstuhl.de/opus/volltexte

14. Sean M. Falconer, Natalya F. Noy, and Margaret-Anne Storey, "Ontology Mapping - A User Survey", Canada

15. Natalya F. Noy and Deborah L. McGuinness, "Ontology Development 101: A Guide to Creating Your First Ontology",Stanford University, Stanford, CA, 94305 